This is an Accepted Manuscript of an article published by Taylor \& Francis in Compare on 22 January 2018, available online: http://dx.doi.org/10.1080/03057925.2018.1425132

\title{
Fair access to higher education and discourses of development: a policy analysis from Indonesia
}

\section{Elisa Brewis}

Department of Education, Practice and Society

UCL Institute of Education, 20 Bedford Way, London WC1H 0AL

\begin{abstract}
The purpose of this paper is to explore the relationship between fair access policies and discourses of development through a policy analysis of higher education reform in postauthoritarian Indonesia (1998 - present). The method was document analysis of five laws/regulations, using the criteria of accessibility, availability, and horizontality to identify the extent of fair access for students from (i) lower socio-economic backgrounds and (ii) underdeveloped regions of the archipelago. The analysis demonstrates how neoliberal, human capital, inclusive development and Pancasila discourses have been called upon in the making and un-making of a HE market, with ultimately favourable outcomes for the fair access agenda.
\end{abstract}

Keywords: higher education; pro-poor development; education policy analysis; Southeast Asia 


\section{Introduction}

Equity or equitably distributed participation in higher education (HE) has become a muchresearched topic in the field of comparative education. In part this reflects the fact that HE systems are no longer purely elite systems, and so there are greater societal expectations for fair access to it. Globally, the current Gross Tertiary Enrolment Rate (GTER) stands at about a third of the age cohort, and may reach the 50\% threshold of 'high-participation systems' (HPS) within the coming generation (Marginson 2016).

The figures reveal an impressive growth in HE participation in quantitative terms, but can we say that access to HE has become more equitably distributed, or fairer? Evidence from a recent attempt to chart a global map of equity (Atherton et al 2016) concludes that inequality in access to HE remains pervasive. Even if there are gains in terms of gender and socio-economic status, it is often difficult to ascertain the extent of fair access in terms of other localised notions of fairness, such as ethnicity, religion, or language. When discussing fair access, scholars have pointed out the need to also consider the quality of the education that is accessed in order for it to be meaningful (Schendel and McCowan 2016). Expanding participation will not necessarily improve educational and life outcomes if a system is characterised by large gaps in quality, or what is known as vertical diversification (Brennan and Naidoo 2008). In other words, massified systems do not automatically lead to more equitable ones.

Analyses at the global level have highlighted the challenge of achieving an equitable HE system for the reason that equity does not exist in isolation from other economic, political or policy contexts. For example, Unterhalter and Carpentier (2010) identify economic growth, democracy and sustainability as the broader structural forces that equity is contingent on. St. John and Meyer (2013) point out that as a public policy issue, equitable HE has inevitably been tied into a balancing act between competing policymaker concerns of excellence and efficiency. This in turn has rendered fair access policies vulnerable to changes in political will and funding commitments.

If these are the challenges, where might opportunities for fair access policies lie? One particularly important factor in facilitating fair access policies seems to be the ideological type of development pursued. For example, large degrees of gender and socio-economic equity were achieved in the post-war Nordic countries thanks to the Welfare State model of development legitimised by economists such as Gunnar Myrdal. This approach assumed a 'virtuous circle between democracy, social justice and economic growth', and used education as a tool to remove social inequalities (Jalava 2013, 81). In East Africa, Kenya and Uganda adopted HE marketisation policies in line with their capitalist state ideologies, whereas in neighbouring Tanzania marketisation was resisted until the 1990s, in part a legacy of ujamaa, a particular conceptualisation of African socialism driven by President Nyerere (Munene 2015).

Taking these insights about political and policy context as a starting point, and in particular the ideological rationales for development, this paper addresses Indonesian fair access reforms in the post-authoritarian period (1999 - present). As middle-income countries represent the new frontier of the HPS trend (Marginson 2016, 414), it seems timely to turn our attention to this context. Furthermore, a new development rationale emphasising the contribution of HE to poverty reduction and social development has pushed HE on the policy agenda (Tilak 2010; Naidoo 2011; Schendel and McCowan 2016). Therefore, it seems relevant to examine the development rationales behind Indonesia's HE reforms. 


\section{The Context of Indonesia}

HE expansion in Indonesia began in the 1980s due to an improvement in secondary school completion rates and a heightened demand for skilled graduates (Hill and Wie 2013, 161). Enrolments grew from less than 1 million pre-1990 (Welch 2007: 669), to 2.68 million in 1995, and by a further million again to 3.87 million in 2005 (Hill and Wie 2013, 161). Currently, enrolments stand at 5.38 million (Pangkalan Data Dikti [Indonesian Higher Education Database] 2016a). Unlike in the European model, expansion in low and middle income (LMI) contexts has been aided by a large private sector. In Indonesia the private sector ${ }^{1}$ accounts for roughly two-thirds of enrolments and 90\% of HEIs (Pangkalan Data Dikti [Indonesian Higher Education Database], 2016b). The pattern of privatisation is mainly that of excess demand, i.e. providing a less competitive alternative to elite state HEIs (Jamshidi et al 2012), although there are also some examples of differentiated demand, i.e. private HEIs providing specialised and high-quality HE, with links to specific industries or professions (e.g. Telkom University in the field of telecommunications, Binus University in the field of creative arts and media). As the private sector has expanded, the state has taken action to regulate it via compulsory accreditation at both the institution and degree programme level - the only country in Southeast Asia to do so (Niedermeier and Pohlenz 2016). Private HEIs are also under state influence via the regional coordinating bodies or KOPERTIS, which dispense competitively-awarded research and infrastructure grants, and other resources such as capacity building or secondment of state HEI staff.

The potential for HE expansion in Indonesia to support rather than exacerbate equity objectives is far from clear. The colonial legacy of regional inequality, with resources concentrated on the island of Java, means that current distribution of HE participation is unequal. Data from the 2012 household survey (SUSENAS) revealed that participation in HE is highly stratified, ranging from as low as $2-3 \%$ in the lowest consumption quintile, to $38 \%$ in the highest quintile (Gao 2015, 87). The likelihood of participation is further compounded by geographic origin, rurality and being female (Gao 2015, 94-5).

Aside from such demographic challenges, perhaps the most important point about the nature of HE expansion in LMI contexts is that countries lack full autonomy over HE policy, as their policies are subject to intervention by supranational organisations and donor agencies (Schendel and McCowan 2016, 408). Soon after the end of General Soeharto's 32-year military rule in 1998, Indonesia's education system underwent a series of marketisation and decentralisation reforms that formed part of a broader IMF/World Bank agenda to liberalise the economy and decentralise the political system (Robison and Hadiz 2004). While the decentralisation reforms have been largely implemented, in accordance with other laws mandating regional autonomy ${ }^{2}$, the marketisation reforms drew controversy over their potential to undermine affordable and fair access to primary, secondary and HE. Ultimately, the process of marketisation was disrupted and the subsequent legal architecture that was set in place with the 2012 Higher Education Law (12/2012) supports fair access via admissions quotas, meanstested tuition fees, and scholarships schemes. Unlike in the case of Chile or Colombia, these results were not achieved via a class-based social movement (cf. Espinoza and Gonzalez 2013).

\footnotetext{
${ }^{1}$ Most private HEIs in Indonesia are established by religious organisations or charitable foundations (yayasan).

${ }^{2}$ Regional Government Law 22/1999 (Undang Undang Nomor 22 Tahun 1999 Tentang Pemerintah Daerah); Financial Redistribution Between the Central and Regional Governments Law 25/1999 (Undang Undang Nomor 25 Tahun 1999 Tentang Perimbangan Keuangan antara Pemerintah Pusat dan Daerah)
} 
Indeed, scholars of Indonesian politics had predicted little room for social justice accountability after the violent annihilation of the communist movement between 1965-66 (Rodan and Hughes 2014), resulting in the 'disorganisation of civil society' under General Soeharto (Robison and Hadiz 2004). Therefore, Indonesia serves as a useful case study to empirically explore how fair access policies have been shaped by competing ideologies of development.

\section{Research Aim and Methods}

Research aim and purpose

For the purpose of this paper, I have narrowed the scope of equity to fair access for students from lower socio-economic backgrounds and under-developed regions. To address the concern of vertical diversification (Brennan and Naidoo 2008), I employ a deliberately broad conceptualisation of fair access put forward by McCowan (2016) that comprises (1) Accessibility (i.e. are the procedures for entering and accessing HE fair); (2) Availability (i.e. are there sufficient places in HE institutions proportionate to the age cohort); and Horizontality (i.e. is there consistent quality across HE institutions rather than stratification of quality). The utility of this framework was demonstrated by applying it to a comparison of HE systems in Brazil, Kenya and the UK, and I wish to demonstrate its utility further by applying it to the Indonesian context here. The specific questions guiding the analysis are:

1. To what extent do the post-1998 Indonesian HE reform mechanisms (e.g. provisions for scholarships, use of admissions quotas) support fair access to HE in terms of accessibility, availability and horizontality?

2. Which ideological discourses of development (neoliberal, human capital, inclusive development, Pancasila) have been mobilised to justify the above mechanisms?

The analysis of the reforms reported here constitutes part of a broader qualitative study into social justice accountability in the Indonesian HE system from the perspective of policymakers and institutional behaviour. However, this paper is deliberately limited to a discussion of the findings at the policy level itself, in other words the macro level of market-making, not the micro-level 'recalibration' or 'reconstitution' of markets by individuals or institutions via social interactions (Komljenovic \& Robertson 2016), or the 'negotiated order' of public policy implementation more generally (Barrett and Fudge 1981). Achieving fair access targets on the ground is contingent on a deeper understanding of the political and policy context for HE reform. Accordingly, the purpose of the discussion presented here is to address this domain as an initial step, enabling us to subsequently locate and explicate HEI/societal behaviour in response to such reforms more critically, both in Indonesia and comparable contexts.

\section{Selection criteria for the reforms}

The analysis adopts a systems-level approach, focussing on fair access policies as prescribed in formal legislation. Informed by Stephen Ball's $(1993,14)$ conceptualisation of policy as discourse, I selected all four education-related laws since 1998 in order to establish the 'accumulative effects' of their 'overarching discourses':

(1) Government Regulation (GR) 61/1999 on the Implementation of State Universities as State-Owned Corporate Bodies

(2) The National Education System Law 20/2003 
(3) The Teachers and Lecturers Law 14/2005

(4) The Educational Corporate Body Law 9/2009

(5) The Higher Education Law 12/2012.

I also included GR 61/1999 because the autonomy policy that it introduced was incorporated and further elaborated in the subsequent laws, rendering it an essential part of the analysis. Although the Law 9/2009 is now defunct after a review by the Constitutional Court overruled $\mathrm{it}^{3}$, I retained this law as it allows us to trace how the debate surrounding fair access has evolved. I also refer to concrete policies and programmes that derive from the legally more authoritative laws (undang-undang) where relevant: the means-tested tuition fee policy: UKT; the scholarship scheme for low-income students: Bidikmisi; the affirmative action policy: ADIK Papua/ADIK 3T; and the National Higher Education Standards: SN Dikti. All English translations provided are my own.

\section{Data analysis}

The method of data analysis employed was qualitative content analysis. Content analysis is a method typically used in communication science and other social science that relies on textual analysis. This method was selected because content analysis enables a systematic method for identifying and classifying content quantitatively, in this case legal provisions that either support of undermine fair access to HE. Each legal document was read in full, and all equityrelevant policy mechanisms were categorised according to the three indicators of accessibility, availability, and horizontality (McCowan 2016), thus producing a comparative description of fair access. Because I was also interested in the discursive dimension to the policy reform process, I chose to employ what is known as the qualitative approach to content analysis. This approach enables the researcher to conduct a more nuanced analysis of 'latent and contextdependent meaning (Schreier 2014, 173), thus enabling a qualitative, interpretive approach to the analysis as well.

Before turning to the analysis of the reforms, I first provide some definitions of the four discourses of development that are most relevant to this case, namely neoliberalism, human capital, inclusive development, and pancasila (the 'five principles' which form the basis for the Unitary Republic of Indonesia). To be clear, this is not intended as an exhaustive list of mutually exclusive categories of development ${ }^{4}$. Rather, the purpose is to define the key terms employed in the analysis hereafter. As the analysis will demonstrate, there can often be overlap between ideological rationales and policy mechanisms from all four of these approaches to development.

\section{Global discourses of development}

\section{Neoliberalism}

Neoliberalism is a mode of capitalism characterised by 'the systematic use of state power to impose (financial) market imperatives’ (Saad-Filho and Johnstone, 2005, 3). In terms of its

\footnotetext{
${ }^{3}$ Constitutional Court of the Republic of Indonesia. 2010. Decision Number 11-14-21-126-136/PUU-VII/2009

${ }^{4}$ In particular, I want to acknowledge that a full discussion of the diverse political movements of twentieth century Indonesia (e.g. Pan-Islam, Islamism, Islamic modernism, Communism, Socialism, Nationalism) is not possible here.
} 
impact on public policy, neoliberalism has replaced 'government' with 'governance', through the corporate-style principles of New Public Management (Samier 2017, 1519). Neoliberalism has impacted the global HE reform agenda from the 1990s onwards, resulting in marketoriented HE systems (Johnstone et al 1998, 3) that depend on non-governmental revenue (for example recovery-cost tuition fees, student loans, private HE provision, entrepreneurial activity, and philanthropy) (Johnstone et al 1998, 6). Alongside this, HE systems have undergone demands for greater accountability, as well as greater quality and efficiency (Johnstone et al 1998, 4-5).

Neoliberal HE policy mechanisms primarily rely on market-making, not state-steering. The role of the state can be to 'guide, regulate and subsidize' (Johnstone et al 1998, 26), thus allowing some degree of state intervention to guarantee accessibility, availability and horizontality. However, its primary emphasis on the market and individual choice makes its contribution to accessibility and availability unclear, as its essential policy strategy is to raise the cost of HE borne by the student/family, and to render availability subject to market demand (i.e. a market comprised of families able to afford tuition fees). It has more to say on horizontality, as it endorses quality assurance and other accountability mechanisms to monitor quality. In practice, St. John and Meyer (2013) argue that neoliberal rationales do not incentivise governments to subsidize access in low-resource contexts, because there is pressure to concentrate funds on the alternative concern of excellence (quality, accountability to global rankings).

\section{Human capital theory}

The policy rationale for HE expansion is often framed in economic terms. HE expansion is pursued in order to increase national competitiveness in the globalised knowledge economy, for example by increasing the proportion of high-skills jobs as the economic structure shifts to favour manufacturing and services (World Bank 2002; Torres and Schugurensky 2002; Naidoo 2011). In other words, this is a discourse of development informed by human capital theory, whereby equity in $\mathrm{HE}$ is desirable because increased participation rates yield greater numbers of skilled labour, and consequently, economic prosperity.

The human capital discourse of development has potential to support a fair access agenda in terms of accessibility and availability. Young people who are qualified and motivated to enter $\mathrm{HE}$, but who cannot do so due to a lack of available or affordable spaces, are framed as wasted economic potential. Therefore, governments are encouraged to employ state-steering mechanisms to maximise HE participation. This discourse has less to say on the aspect of horizontality, although indirectly an assumption is made that HE should be of sufficient quality and relevance to enable an efficient transition of graduates to the labour market.

\section{Inclusive development}

Amartya Sen (1999) has famously argued for a human capability approach to complement the economically defined human capital argument for development. The aim of development, he argues, should be to enable citizens' capability to pursue freedoms that enhance their material and social well-being, with an emphasis on their capacity to participate in democratic discussion over those decisions about what kind of development is desirable.

The capability approach has had an impact on global discourses of development, manifesting in various iterations. Within the international development community, a growing number of political scientists have broadened their focus beyond a narrow definition of development as a 
'primarily economic process', to 'one with an integral focus on the achievement of equity and the rights of citizenship' (Hickey 2013, 3), or what is known as inclusive development. For instance, the Centre for Effective States and Inclusive Development (ESID) defines inclusive development as occurring: ' ... when social and material benefits are equitably distributed across divides within societies (across income groups, genders, ethnicities, regions, religious groups and others).' (Hickey 2013, 3, footnote 1). We can view the Education for All movement, and the progression of the Millennium Development Goals (MDGs) into the Sustainable Development Goals (SGDs) as a further iteration of this trend. Goal 4 of the SDGs on education now includes both equity and quality dimensions: 'Ensure inclusive and equitable quality education and promote lifelong learning opportunities for all' (UN 2015).

Concretely, inclusive development objectives for HE have been prescribed for the purpose of eradicating racial inequalities in post-Apartheid South Africa (Cloete and Moja 2005), in Brazil as part of the National Affirmative Action Plan (PNAA) (Somers et al 2013), and for achieving gender parity in Ghana (Manuh et al, 86-7). These are often referred to as social justice or social cohesion arguments for development. For the sake of consistency and clarity, in this paper I use the single term inclusive development to capture all the approaches described above (human capability, inclusive development, social justice or social cohesion).

An inclusive development discourse provides a powerful basis for pursuing all three of the fair access criteria - accessibility, availability and horizontality. It does so by going beyond a purely economic rationale for investing in access to $\mathrm{HE}$, instead linking the fair access agenda to a broader goal of societal equity, using a socially-embedded framing of personal growth and well-being. Compared to neoliberalism and human capital theory, this discourse is comparatively broad, without explicitly advocating recourse to specific policy mechanisms or economic strategies. Instead, these are heterogenous and locally-defined projects. ${ }^{5}$

\section{Pancasila}

The discourse of national development in post-colonial Indonesia has been dominated by the state ideology Pancasila (lit: the five principles). Pancasila is unique in that it prescribes a semi-secular yet religiously defined principle of co-existence as a nation state, borne out of a political need to unite the diverse anti-colonial groups (Islamist, Nationalist, Communist) at the declaration of independence on 17 August 1945. In theory Pancasila advocates a participatory and pro-social justice approach to development, as expressed in the $4^{\text {th }}$ and $5^{\text {th }}$ principles:

1) Belief in the one and only God

2) Just and civilized humanity

3) The unity of Indonesia

4) Democracy guided by the wisdom of consensus arising out of deliberation among representatives

5) Social justice for the entire people of Indonesia

In practice, the call for social justice/equity via democratic deliberation has been overshadowed by a focus on maintaining political unity and social cohesion among diverse religious and ethnic groups, i.e. the $1^{\text {st }}$ and $3^{\text {rd }}$ principles. Under General Soeharto in particular (1965-1998 - the so-called New Order period), Pancasila was subsumed by a neo-traditionalist discourse

\footnotetext{
${ }^{5}$ While the discourse is moral in tone and oriented around social justice, it is not pinned down to a particular philosophical, political or religious framing (e.g. capitalism, socialism, liberation theology, pan-Islam).
} 
to legitimise repressive state actions (Anderson 1990) and subdue alternative, Islamic claims to authority (Furchan 1993; Keyes, Kendall and Hardacre 1994). This new orientation of development supplanted an earlier nationalism of the 1950s that had been characterised by a pro rakyat $^{6}$ solidarity with the poor (Schulte Nordholt 2011, 390).

What then, has ensued since the end of the New Order regime? Has the Reformasi (reform) era presented new opportunities for Pancasila to be re-mobilised for a social justice agenda? Initially, this looked unlikely. In the period immediately after the 1997 Asian financial crisis, structural adjustment programmes (SAP) were signed with the IMF/World Bank, which appeared to set the development agenda firmly on the course of extensive neoliberalisation (Robison and Hadiz 2004) with unclear results for a social justice/equity agenda. Gellert (2015) has even argued that the neoliberal emphasis on individual choice and agency is espoused by a new class of urban intellectuals, who express a religiously-couched 'optimistic' discourse of development that fails to seriously engage with structural inequalities. This is reminiscent of contemporary critiques of African socialism, such as Matolino and Kwindingwi's (2013) indictment of ubuntu in post-apartheid South Africa as an elite-driven 'narrative of return' that fails to address the lived experience of non-elite South Africans.

At the same time, the Reformasi movement brought about decentralisation of power to the provincial level, electoral reform designed to diversify politics, the establishment of a corruption eradication commission, constitutional reform, and the establishment of the Constitutional Court (Crouch 2010). In this environment, a more pro-citizen, inclusive type of development has materialised to a limited extent in the context of land reform and mining in protected forests (Rosser, Roesad and Edwin 2004), improved performance of local governments (Von Luebke 2011), and in education (Rosser 2015a). Amendments to the constitution made between 1999 and 2002 include the enshrinement of the right to 'receive an education ${ }^{7}$ as well as a stipulation to allocate $20 \%$ of the state budget to education ${ }^{8}$. The above examples suggest that there might be scope for a reorientation of Pancasila to the $4^{\text {th }}$ and $5^{\text {th }}$ principles of democratic participation and social justice. It seems prudent to concur with Christian Von Luebke (2011) when he concludes that the contemporary Indonesian policy context is characterised by 'a confluence, or competition of obstructive and progressive elements' (2).

\section{Research Findings and Discussion}

The post-authoritarian reforms can be categorised into three main phases: the first phase of market-preparing; the second phase where market-making was intensified; and finally the unmaking (or at least tempering) of the market. Overall, I show that those reforms containing the fewest policy mechanisms in support of a fair access agenda mainly mobilised neoliberal and human capital discourses of development, whereas those reforms with the highest incidence of policy mechanisms in support of fair access mainly mobilised human capital, inclusive development and Pancasila discourses.

\footnotetext{
6 'the masses', 'the people'

${ }^{7} 1945$ Constitution of the Republic of Indonesia Article 28 C (2nd round of amendments), 31 (1) (4th round of amendments)

${ }^{8}$ Article 31 (4) (4 ${ }^{\text {th }}$ round of amendments)
} 


\section{The first phase: market-preparing}

Government Regulation on the Implementation of State Universities as Corporate Bodies (PP 61/1999)

This regulation introduced a new autonomous status for nominated high-performing state universities, known as 'educational corporate body' (ECB) status (badan hukum milik negara or BHMN) ${ }^{9}$. This status awards them managerial, financial and academic autonomy, although the Minister of Education ${ }^{10}$ retains influence via voting rights in the Council of Trustees and executive oversight more generally. In terms of fair access, the regulation undermines all three criteria of accessibility, availability, and horizontality.

Firstly, it should be acknowledged that the reform does not aim to address fair access in the system overall, as it only relates to a small category of state HEIs. Nevertheless, evidence from the first four state universities to convert to ECB status in $2000^{11}$ demonstrates how accessibility and availability were undermined. Granting autonomy to ECB universities was contingent on a cut in state funding. The solution employed by HEIs to offset this reduction in revenue was raising tuition fees (Welch 2007). A particularly controversial strategy was the introduction of the 'non-regular route' admissions system (jalur khusus ${ }^{12}$ ). It guarantees a place on a degree programme for a minority of students who pay dramatically higher fees ${ }^{13}$. Higher education institution managers were hence employing a cross-subsidization strategy which allowed them to soften a potentially greater fees hike for the majority of students selected on merit (i.e. performance in the national university entrance exam) (Susanto and Nizam 2009). Nevertheless, the non-regular route clearly disadvantages students from lower socioeconomic backgrounds, as a proportion of the intake is in effect 'reserved' for those students whose parents can afford to pay high fees.

In terms of horizontality, the reform arguably promotes quality within the system by granting state HEIs the autonomy necessary to innovate in terms of curriculum design, industry linkages and third sector engagement. However, because ECB status is limited to elite state universities, it does little to address horizontality across the sector. In effect, quality HE (as defined in the reform) is the preserve of those HEIs that have historically been the best resourced and most able to attract quality students.

In terms of the policy mechanisms adopted, we can clearly identify a neoliberal strategy in the 61/1999 Regulation (autonomy, quality, efficiency of state funds via semi-privatisation of state provision). When we examine the discourses of development that frame the reform, a neoliberal concept of competition dominates. In the Presidential Preamble to the law and the Guidelines, economic competition brought about by globalisation is used to justify the need for reform,

\footnotetext{
${ }^{9}$ Literally, state-owned corporate body. In the 2003 and 2009 Laws, this was changed to badan hukum pendidikan or educational corporate body. For the sake of clarity, I use the term ECB status throughout.

${ }^{10}$ At the time this law was passed (1999) this was the Minister for Education and Culture. Since the 2014 restructuring of the cabinet under the Joko Widodo-Jusuf Kalla administration, it is the Minister for Research and Technology and Higher Education.

${ }^{11}$ These were: Institut Teknologi Bandung, Universitas Gadjah Mada, Institut Pertanian Bogor, Universitas Indonesia.

${ }^{12}$ Alternative terms include jalur mandiri [independent route] or biaya kuliah pilihan [optional fee structure].

${ }^{13}$ For example, Institut Tekonologi Bandung reportedly advertised fees of 225 million IDR (currently 16500 US\$) for itss Physical Engineering department in the mid-2000s (Welch 2007, 679). For comparison purposes, students on the current UKT means-tested fees structure pay between 1 and 10 million IDR (currently $\sim 75-750$ US\$).
} 
epitomised by the Asian financial crisis of 1997. Competitive HEIs, it is argued, will advance overall national competitiveness. At the same time, the function of HEIs is framed in human capital terms, namely promoting knowledge for development, with science and the arts used for direct benefit of all citizens (Article $3 \mathrm{~b}$ ). Alongside this, autonomous HEIs are conceptualised as independent entities beyond the state providing the 'moral force' needed to promote civil society ideals, political tolerance, freedom, justice, humanity and solidarity in line with the post-Soeharto Reformasi agenda (Article 3 c, Guidelines p.2). We could construe this second dimension to development as a re-orientation of Pancasila to the $2^{\text {nd }}, 4^{\text {th }}$ and $5^{\text {th }}$ principles about democratic participation and social justice, although the supposed link to the policy mechanisms is unclear.

The National Education System Law (UU 20/2003)

This is a comprehensive law that addresses both state and non-state education sectors from primary to tertiary level, replacing National Education System Law 2/1989. Accessibility, availability and horizontality are each addressed to a fair extent, although many of the principles (1) were in contradiction with a simultaneous provision (Article 53) to marketise the entire education sector; and (2) did not lead to concrete programmes or regulations until after the subsequent Higher Education Law 12/2012.

Accessibility is addressed explicitly in the law through provisions of affordability of education. Chapter 5 outlining students' rights and obligations includes ambitious goals for improving equal access to education. Every student in every school/HEI has the right to either (1) $a$ scholarship if they are bright and their parents cannot afford to put them through school/HE, or (2) tuition fee waivers if their parents cannot afford to put them through school/HE (Article $12[1] \mathrm{c}-\mathrm{d})$.

Availability is addressed via provisions for state funding of education. In line with the constitutional amendment of 2002 (Article 31 [4]), the 2003 law mandates 20\% of the State/Regional budget to be allocated to education, excluding salaries for teaching staff (Article 49 [1]). However, as HE typically represents a minor portion of this budget, funding safeguards for HE that might contribute to sufficient availability were less clear. This was especially so considering that Article 53 called for expansion of ECB status nationally.

Horizontality is addressed quite explicitly. Article 5 (1) states that every citizen has an equal right to access quality education. One of the main purposes of the law was to introduce a National Standard of Education (Chapter 9). This could be considered a more far-sighted strategy than policies that intervene at the point of HE entry (quotas for disadvantaged groups, affirmative action). In particular, the aim of the policy to "eliminate discrimination between state and non-state schools as well as differentiation between religious as well as general education' (Guidelines Section 1) addresses the structural changes necessary to improve secondary education as a conduit to HE.

Of all the reforms included here, the discourse of development in the National Educational Law $20 / 2003$ is the most heterogenous. The law is framed primarily in moral terms, referring to the constitutional aim to 'develop the intellectual life of the nation' (mencerdaskan kehidupan bangsa) as well as the same civil society ideals outlined in GR 61/1999 (democracy, human rights, justice) (Presidential Preamble a - c), again attributed to the Reformasi movement (Guidelines Section 1). This inclusive development dimension is further aligned to a Pancasila discourse through explicit references to the state's religious and political pluralism (the $1^{\text {st }}$ and 
$3^{\text {rd }}$ principles). For example, Article 4 (1) states that the provision of education should be 'democratic, just, and non-discriminatory, all the while upholding human rights, religious values, cultural values, and the plurality of the nation' (emphasis added). The policy mechanisms themselves support a human capital and inclusive development approach as evidence in provisions for state funding of education (both for institutions and students via scholarships/tuition fee waivers) and horizontality of quality. Alongside this, a neoliberal discourse is mobilised to promote efficiency and accountability of school and university management. In terms of a market/competition logic, the Law upholds and even expands the ECB policy.

The Teachers and Lecturers Law (UU 14/2005)

The Teachers and Lecturers Law 14/2005 does not address provision of HE per se, and accordingly does not address the availability and accessibility dimensions of fair access. It does, however, reiterate a state commitment to improving the horizontality dimension. The major policy change introduced in this reform was the certification policy (sertifikasi) whereby all teachers and lecturers receive enhanced remuneration in exchange for obtaining appropriate qualifications. The rationale expressed for this policy is that it is necessary to empower and raise the quality of teachers and lecturers in order to achieve the policy objectives of widening access, raising the quality and relevance of education, and good governance and accountability in education (Presidential Preamble, b). Teaching posts at schools and universities in underdeveloped 'special regions' (daerah khusus) are also incentivised (Article 55) in an attempt to distribute qualified lecturers more evenly across the archipelago. The Law draws on the same human inclusive development and Pancasila discourses introduced in National Education System Law 20/2003, adding the human capital arguments of 'development' and 'prosperity' as objectives for the education system (Presidential Preamble a). A neoliberal discourse is limited to the efficiency and accountability of education management.

\section{The second phase: market-making}

The previous phase demonstrated elements of marketisation alongside continued use of statesteering mechanisms. This market-preparing stage was amplified in 2009 when a separate law on ECB status was finally passed by parliament - The Educational Corporate Body Law 9/2009. The primary aim of the law was to create an education market, with competition between schools/HEIs driving up quality. It represents a more complete neoliberal approach, as it includes (1) the marketisation element of diversifying funding to non-governmental sources, (2) competition as a driver of behaviour (e.g. unsuccessful schools/HEIs faced punitive action in the form of liquidation or mergers - see Articles 57 - 58); and (3) accountability and quality assurance activities on the part of the state. The terminology used in the law also reflects this, for example defining the purpose of a school/HEI as 'to provide the service of education' (memberikan layanan pendidikan); reference to the duty of a university to offer a 'prime service' (layanan prima). Interestingly, the wording 'state-owned' from the BHP nomenclature was dropped (i.e. from badan hukum milik negara to badan hukum pendidikan), signalling a more comprehensive shift toward marketisation. ${ }^{14}$

\footnotetext{
14 The wording 'state-owned' in GR 61/1999 may have been used to distance the reform from other ongoing deregulation projects at the time, whereby state-owned enterprises were sold off.
} 
The law had potential to undermine both accessibility and availability at the same time. In terms of affordability of $\mathrm{HE}$, the introduction of the 'non-regular route' admissions system at the existing ECB universities previewed a likely scenario of tuition fee hikes (Welch 2007, Susanti 2011). We know from the literature on school dropout in Indonesia that even under a heavily state-subsidised funding structure, schools continue to levy informal costs from students (for example for textbooks, uniforms, contributions to school infrastructure projects) to a prohibitive extent, resulting in dropout (Widoyoko 2010; Rosser and Joshi 2013). It is therefore reasonable to assume that faced with reduced state funding, state schools and HEIs would pass on the extra costs to students/parents. Hence the law had potential to make HE prohibitive on two levels - by making it costly to complete secondary school, and even more costly to enter HE.

At the same time, the 2009 ECB law did address accessibility through a number of provisions, probably in an attempt to pre-empt and curb some of the unfair consequences of the earlier ECB reform (GR 61/1999). Firstly, the means-tested tuition fee policy mentioned in National Education System Law 20/2003 was reiterated (Article 41 [7]). More dramatically, Article 46 mandated a $20 \%$ student admissions quota for low-income students with academic potential, as well as scholarships or financial assistance for these students. Article 41 (5-6) also included provisions for the state to contribute $50 \%$ of operational costs at state HEIs, as well as $100 \%$ of investments, tuition waivers and scholarship disbursements. Finally, Article 41 (9) imposed a cap on income generated from tuition fees, limiting this to maximum $30 \%$ of an ECB's operational costs.

Beyond the policy text itself, reactions to the ECB reforms indicate that HEI practitioners, students and parents alike rejected its neoliberal rationales. Several nationalist/leftist Indonesian academics based at ECB and non-ECB state universities launched an ideological critique against ECB status (Nugroho 2002; Darmaningtyas, Subkhan and Fahmi-Panimbang 2009). Four of the five petitioner groups that demanded a review of the 2009 ECB Law by the Constitutional Court all made reference to a neoliberalisation/commercialisation of education and a neglect on the part of the state to guarantee the constitutional right to education. ${ }^{15}$ The Court decision partly acknowledged these concerns, although in its decision to overturn the law in 2010, other aspects regarding the legality of mandating ECB status for non-state schools and HEIs were highlighted as stronger grounds for rejection.

\section{The third phase: the un-making of the market}

After the 2009 ECB Law was overturned, a subsequent law was passed that relates specifically to HE - The Higher Education Law 12/2012. It builds on many of the pro-fair access principles already established in the 2003 National Education System Law, and signals a consolidation of human capital, inclusive development and Pancasila arguments amidst the erosion of neoliberal ones. The Law opens with a strong claim that 'a well-planned, guided and

\footnotetext{
${ }^{15}$ Request for review of the 2003 National Education System Law and 2009 Educational Corporate Body Law by Petitioner Group 1 (11/PUU-VII/2009), Petitioner Group 2 (14/PUU-VII/2009), Petitioner Group 3 (21/PUU-VII/2009), Petitioner Group 5 (136/PUU-VII/2009). Petitioner Group 4 (126/PUU-VII/2009), which comprised the Association of Private Universities of Indonesia as well as 13 foundations that run private HEIs, argued alternatively that the obligation for all universities to conform to ECB status unfairly abolished their hitherto legal status as charitable foundations (yayasan).
} 
sustainable approach to HE governance' is necessary for the 'realisation of social justice in access to HE that is of high quality', and to ensure relevance to the public good interests of 'development, independence and prosperity' (Presidential Preamble d). Social justice is defined in general terms as 'democratic, just and non-discriminatory' provision of HE (Article $6 \mathrm{~b}$ ), as well as in very specific terms as 'advocating for those groups in society who are less well-off' (Article 6 i). Like the 2003 Law, the text draws authority from the constitutional aim to 'develop the intellectual life of the nation' (mencerdaskan kehidupan bangsa). It mobilises a discourse on national development in terms of both economic prosperity and technological advancement (human capital), as well as tolerance, democracy and human rights (inclusive development). The purpose of education is defined repeatedly in terms of the $1^{\text {st }}$ and $3^{\text {rd }}$ principles of Pancasila; that is, religiosity (e.g. people of faith, people loyal to the One True God) and commitment to the unitary state of Indonesia (e.g. tolerant, upholding unity and national integration). In terms of policy mechanisms, the Law supports accessibility and horizontality, and to a lesser degree availability (i.e. via continued state funding and provision of HE).

Accessibility is addressed in terms of affordability via the use of a means-tested fees system (Article 76 [3]). This provision has resulted in a specific policy known as the UKT or standardised tuition fee system, driven by the Director General of Higher Education (DGHE) at the time, Djoko Santoso (2010-2014). Students at all state HEIs (including ECB ones) are categorised into one of five fee categories based on parental income brackets. The full cost of each study programme, as well as the subsidised rate of each fee category is detailed in an annual ministerial regulation ${ }^{16}$. Students in the lowest groups typically pay between 500,000 2 million IDR per semester. State-ECB HEIs still have the freedom to admit students at nonUKT rates, but this is capped to $30 \%$ of the intake (echoing Article 41 [9] of the defunct BHP Law 9/2009).

The provision for means-tested fees coupled with financial aid for poor students in Article 76 already had a precedent in Article 12 (1) c-d) of the 2003 Law, and Article 41 of the 2009 Law. After the latter was overturned in 2010, and concurrent to the drafting of the subsequent 2012 HE Law, the Minister and the DGHE went ahead and launched the Bidikmisi Scholarship programme in 2010 to deliver on this aim. Bidikmisi covers tuition fees (set at a fixed price, currently 2.4 million IDR) and a maintenance grant (currently 650,000 IDR per month). Applicants apply through one of the DGHE-run entry routes, either the national entrance exam Seleksi Bersama Masuk Perguruan Tinggi Negeri (SBMPTN), or the high-school report entry route Seleksi Nasional Masuk Perguruan Tinggi Negeri (SNMPTN). There are no provisions for leniency in academic selection. The programme was extended to the private sector as well in 2012. Although Bidikmisi was launched as early as 2010, the inclusion of Article 76 in the 2012 Law is significant as it provides a more authoritative legal mandate for the scheme (undang-undang as opposed to Ministerial regulation), which may help to sustain its funding in the future.

Another major feature of the 2012 Law is that it repeats the $20 \%$ admissions quota for disadvantaged students from the 2009 ECB Law, adding the condition to distribute these

\footnotetext{
${ }^{16}$ The most recent one is Ministerial Regulation 39/2017 (Peraturan Menteri Riset, Teknologi, dan Pendidikan Tinggi Republik Indonesia Nomor 39 Tahun 2017 Tentang Biaya kuliah tunggal dan uang kuliah tunggal Pada Perguruan Tinggi Negri di Linagkungan Kementerian Riset, Teknologi, dan Pendidikan Tinggi)
} 
students across the full range of degree programmes available. The scope of 'disadvantage' is now broadened to (1) low-income status and (2) residency in the country's most isolated and deprived regions (terdepan, terluar dan tertinggal) (Article 74 [1]). In line with this, a second scholarship programme was introduced in 2012, namely ADIK Papua/3T. This is an affirmative action scheme whereby students from West Papua province and other underdeveloped regions designated by the government ${ }^{17}$ apply to state HEIs through a separate admissions process with lower standards than the national SBMTPN exam or SNMPTN highschool report route (Ministry for Research and Technology and Higher Education 2016). The scheme covers tuition fees as well as a maintenance grant. Because the scheme has an element of redressing political isolation and fostering socio-cultural integration with other Indonesians, students must apply to HEIs beyond their domicile.

The law also addresses horizontality by maintaining a firm regulatory hold on both the state and private sector in terms of quality assurance and curriculum standardisation. This is the clearest indication of a neoliberal approach in the law (accountability, quality). Article 58 prescribes the unilateral adoption of National Higher Education Standards, commonly referred to by the acronym SN Dikti across both state and private sectors ${ }^{18}$. Accreditation is also enhanced (Article 55), with degree programme accreditation incorporating compliance with SN Dikti. This is a more interventionist approach to regulation of the private sector compared to other HE systems, where regulation is often implemented indirectly via accreditation or other output-based indicators. For example, the National System of Higher Education Evaluation is used in Brazil to monitor students' learning outcomes in the private sector.

\section{Conclusion}

In terms of policy mechanisms that support or hinder fair access, the current Indonesian HE legislation addresses the three dimensions of accessibility, availability and horizontality via the $20 \%$ admissions quota for low-income students/students from disadvantaged regions, the UKT means-tested tuition fee policy, as well as the Bidikmisi and ADIK scholarship schemes. The potential for fair access to be undermined by the creation of state-ECB universities has been tempered by a Ministerial regulation that caps their non-UKT student intake to $30 \% \mathrm{~s}$. Horizontality is addressed across the state and private sector by mandating the use of the National Higher Education Standards (SN Dikti), mandatory accreditation, and the continued support of private HEIs (however limited) through the KOPERTIS. In sum, we can say that accessibility and availability are addressed via policy mechanisms typically advocated by the human capital and inclusive development approaches. Meanwhile, neoliberal policy mechanisms have been limited to the sphere of accountability and quality, with limited marketisation (i.e. via the ECB policy).

While the use of means-tested fees and financial aid may not seem like particularly radical measures, in the context of the failed 2009 ECB Law they represent a remarkable policy shift in favour of the fair access agenda. Taking a comparative perspective with other LMI countries, the 2012 Higher Education Law is also quite striking in that the $20 \%$ affirmative action quota must be distributed throughout the full range of degree programmes offered (Article 74 1). The

\footnotetext{
${ }^{17}$ In the 2016 selection round, these comprised: Aceh, West Sumatera, Bangka Belitung, East Java, Banten, East Nusa Tenggara, Kalimantan, East Kalimantan, North Sulawesi, Southeast Sulawesi, Gorontalo, Maluku, and North Maluku.

18 This is further detailed in Ministerial Regulation 44/2015 On National Higher Education Standards
} 
ACCESS project in Colombia in contrast has prioritised enrolment of low-income students in shorter, vocational degree programmes as a cheaper alternative to post-secondary access. Vocational programmes were made attractive by lowering entry standards (Uribe 2013, 116) and by offering full-cost tuition fee loans for $2-3$ year programmes rather than the $75 \%$ offered for longer degree programmes (Uribe 2013, 118). Of course, participation by private HEIs in Bidikmisi is voluntary, which suggests there may be difficulties in achieving the 'full distribution across programmes' principle there. This is because tuition fees for high-cost study programmes (such as nursing, dentistry, pharmacy) far exceed the 2.4 million IDR state contribution to tuition fees under the scheme. However, the voluntary nature of the participation (without any ancillary perks) may help in curbing predatory HEI behaviour. As a counter example, the PROUNI scholarship scheme in Brazil allows students to access private HEIs, who are set a 10\% quota in exchange for tax breaks (Somers et al 2013). The HEIs can enrol PROUNI students in any number of degree programmes. Anecdotally, this can result in the HEIs profiting from the scheme, when enrolment of PROUNI students is concentrated on low-cost humanities degree programmes (and hence does not match the amount saved via tax breaks).

In terms of the discourses of development that were mobilised behind fair access policies in Indonesia, the analysis has demonstrated a concurrent use of human capital arguments for development (knowledge production, applied sciences, economic prosperity), as well as inclusive development and Pancasila arguments for development (democratic participation, social justice). This has taken place amidst a gradual erosion of neoliberal arguments for development (market logic, efficiency, individual choice). As a cautionary note, it remains to be seen whether fair access to HE remains a largely quantitatively defined project, with a focus on quotas and enrolments, without consideration for qualitative educational, employment and life outcomes. For example, there has been no significant movement to address the politics of recognition rather than redistribution, as evidenced by the kind of indigenous education practiced in Latin America (Oyarzún et al 2017).s

Considering the Indonesian public policy context, it is important to note the endurance of Pancasila in the post-Soeharto era. In the domain of education policy at least, it has not become obsolete. Interestingly, it seems to have been rebranded or reconceptualised by policymakers and politicians/legislators alike to justify their respective agendas. Thus we can view the HE education reform process and the controversy surrounding fair access to education as a microcosm of post-Soeharto political manoeuvrings, reflecting competing efforts to redefine the national development agenda. Even if we take the cynical view that indigenous discourses of development are mere ideological dressing for political moves (which are motivated more powerfully by vote-seeking behaviour, for example as demonstrated by Rosser 2015b), or elitedriven neo-traditionalist projects lacking substantive solutions to modern-day post-colonial problems (Matolino and Kwindingwi 2013), the endurance of a Pancasila discourse in this instance is significant. It suggests that indigenous discourses of development can serve as potent tools alongside human capital arguments for pursuing fair access policies.

In terms of implications for our understanding of the equity-development relationship, the case of Indonesia provides further empirical support to counter the convergence model of globalisation, highlighting instead the way in which a country's sociocultural and political context mediates neoliberal policies, producing diverse outcomes (Torres and Schugurensky 2002; Naidoo 2011). The mobilisation of a Pancasila discourse of development in Indonesia's 
HE reforms also suggests that human capital arguments alone are not sufficient to challenge neoliberalisation, probably because a purely economic rationale lacks the value-laden discourse necessary to garner support for public expenditure, especially when resources are tight.

\section{Disclosure statement}

No potential conflict of interest was reported by the author. 


\section{References}

Anderson, B. 1990. Language and Power: Exploring political cultures in Indonesia, Ithaca; London: Cornell University Press.

Atherton, G., Dumangane, C., and Whitty, G. 2016. Charting Equity in Higher Education: Drawing the Global Access Map. London: Pearson.

Ball, S. 1993. "What is policy? Texts, Trajectories and Toolboxes." Discourse: Studies in the Cultural Politics of Education, 13 (2) 10-17.

Barrett, S. M., and Fudge, C. 1981. Policy and action: essays on the implementation of policy. London: Methuen.

Brennan, J. and Naidoo, R. 2008. "Higher education and the achievement (and/or prevention) of equity and social justice." Higher Education 56 (3), 287-302.

Cloete, N. and Moja, T. 2005. "Transformation Tensions in Higher Education: Equity, Efficiency, and Development." Social Research 72 (3) 693-722.

Crouch, H. 2010. Political reform in Indonesia after Soeharto. Singapore: ISEAS Publishing.

Darmaningtyas, E. Subkhan, E. and I. Fahmi-Panimbang 2009. Tirani Kapital Dalam Pendidikan: Menolak UU BHP (Badan Hukum Pendidikan) [The Tyranny of Capital in Education: Rejecting The ECB Law] Yogyakarta: Pustaka Yashiba and Damar Press.

Gao, S. 2015. The Measurement of Tertiary Education Quality in Indonesia through the Educational Production Function Model and Policy Recommendations for Quality Improvement. Unpublished PhD diss., University of Pittsburgh. http://dscholarship.pitt.edu/24173/1/ETD_2015_Dissertation_Shang_GAO6_.pdf

Espinoza, O. and Gonzalez, L. E. 2013. "Causes and Consequences of the Student Protests in Chile." In Fairness in Access to Higher Education in a Global Perspective: Reconciling Excellence, Efficiency, and Justice. Edited by Hanz-Deiter Meyer, Edward P. St. John, Maia Chankseliani and Lina Uribe, 239-255. Rotterdam: Sense.

Furchan, A. 1993. Developing pancasilaist muslims: Islamic religious education in public schools in Indonesia. Jakarta: Logos.

Gellert, P. K. 2015. "Optimism and Education: The New Ideology of Development in Indonesia." Journal of Contemporary Asia 45 (3) 371-393.

Hickey, S. 2013. Thinking about the politics of inclusive development: towards a relational approach. ESID Working Paper No. 1. Effective States and Inclusive Development (ESID) http://www.effective-states.org http://dx.doi.org/10.2139/ssrn.2425235

Hill, H. and Wie, T. K. 2013. "Indonesian universities: rapid growth, major challenges." In Education in Indonesia, edited by Daniel Suryadarma and Gavin Jones, 160-179. Singapore: Institute for Southeast Asian Studies. 
Jalava, M. 2013. "The Finnish Model of Higher Education Access: Does Egalitarianism Square With Excellence?" In Fairness in Access to Higher Education in a Global Perspective: Reconciling Excellence, Efficiency, and Justice. Edited by Hanz-Deiter Meyer, Edward P. St. John, Maia Chankseliani and Lina Uribe, 79-94. Rotterdam: Sense.

Jamshidi, L., Arasteh, H., Naveh Ebrahim, A., Zeinabadi, H., Rasmussen, P.D. 2012. "Developmental patterns of privatization in higher education: a comparative study." Higher Education, 64 (6) 789-803.

Johnstone, D. B., Arora, A. and Experton, W. 1998. The Financing and Management of Higher Education: A Status Report on Worldwide Reforms. Washington, DC: World Bank.

Keyes, C. F., Laurel Kendall and Helen Hardacre, eds. 1994. Asian Visions of Authority: Religion and the Modern States of East and Southeast Asia. Honolulu: University of Hawaii Press.

Komljenovic, J. and Robertson. S. 2016. "The dynamics of 'market-making' in higher education." Journal of Educational Policy 31 (5) 622-636.

Marginson, S. 2016. The worldwide trend to high participation higher education: dynamics of social stratification in inclusive systems. Higher Education 72 (4) 413-434.

Matolino, B. and Kwindingwi, W. 2013. "The end of ubuntu", South African Journal of Philosophy, 32:2, 197-205.

McCowan, T. 2016. "Three dimensions of equity of access to higher education." Compare 46 (4) 645-665.

Ministry for Research and Technology and Higher Education. 2016. Press release No. 13/SP/HM/BKKP/VI/2016. https://ristekdikti.go.id/seleksi-adik-2016/

Munene, I. 2015. Profits and Pragmatism: The Commercial Lives of Market Universities in Kenya and Uganda. SAGE Open. 5 (4): 1-14. doi: 10.1177/2158244015612519.

Naidoo, R. 2011. "Rethinking Development: Higher education and the new imperialism." In Handbook on Globalization and Higher Education, edited by Roger King, Simon Marginson and Rajani Naidoo. 40-58. Cheltenham: Edward Elgar.

Niedermeier, F. and Pohlenz, P. 2016. Higher Education Quality Assurance in the ASEAN Region: State of Affairs and Development Needs. Jakarta: SHARE.

Nugroho, H., ed. 2002. McDonaldisasi Pendidikan Tinggi [The McDonaldsisation of Higher Education] Yogyakarta: Kanisius.

Oyarzún, J. de D., Perales Franco, C. and McCowan, T. 2017. "Indigenous higher education in Mexico and Brazil: between redistribution and recognition." Compare 47 (6) 852-871.

Pangkalan Data Dikti. 2016a. Grafik Jumlah Mahasiswa Aktif Berdasarkan Jenis Kelamin. [Total of Active Students According to Gender] http://forlap.ristekdikti.go.id/mahasiswa/homegraphjk 
Pangkalan Data Dikti. 2016b. Rekap Nasional Semester 2016/2017 Ganjil. [National Summary Statistics 2016/17 Semester] http://forlap.dikti.go.id/

Robison, R. and Hadiz, V. 2004. Reorganizing Power in Indonesia: the politics of oligarchy in an age of markets. New York: Routledge.

Rodan, G. and Hughes, C. 2014. The Politics of Accountability in Southeast Asia: The Dominance of Moral Ideologies. Oxford: Oxford University Press.

Rosser, A., Roesad, K. and Edwin, D. 2004. Indonesia: the politics of inclusion. Working paper series, 229. Brighton: Institute for Development Studies (IDS).

Rosser, A. and Joshi, A. 2013. "From user fee to fee free: The politics of realising universal free basic education in Indonesia." Journal of Development Studies 49(2), 175-189.

Rosser, A. 2015a. "Law and the Realisation of Human Rights: Insights from Indonesia's Education Sector.” Asian Studies Review 39 (2) 194-212.

Rosser, A. 2015b. 2Neo-liberalism and the politics of higher education policy in Indonesia." Comparative Education 52 (2) 109-135.

Saad-Filho, A. and Johnstone, D. 2005. "Introduction" in Neoliberalism: A critical reader. Edited by Alfredo Saad-Filho and Deborah Johnstone. 1-6. London: Pluto Press.

Samier, E. A. (2017) "Neoliberalism.” In Encyclopedia of Educational Philosophy and Theory. Edited by Michael Peters, 1518-1523. Singapore: Springer.

Schendel, R. and McCowan, T. 2016. "Expanding higher education systems in low- and middle-income countries: the challenges of equity and quality" [editorial notes] Higher Education 72 (4) 407-411.

Schreier, M. 2014. "Qualitative content analysis." In The Sage handbook of qualitative data analysis, edited by Uwe Flick, 170-183. Thousand Oaks, CA: Sage.

Schulte Nordholt, H. 2011. "Indonesia in the 1950s: Nation, modernity and the post-colonial state." Bijdragen tot de Tall-, Land- en Volkenkunde, 167 (4) 386-404.

Sen, A. 1999. Development as Freedom. Oxford: Oxford University Press.

Somers, P., Morosini, M., Pan, M., and Cofer Sr, J. 2013. "Brazil's Radical Approach to Expanding Access for Underreprestned College Students." In Fairness in Access to Higher Education in a Global Perspective: Reconciling Excellence, Efficiency, and Justice. Edited by Hanz-Deiter Meyer, Edward P. St. Jon, Maia Chankseliani and Lina Uribe, 203-221. Rotterdam: Sense.

St. John, E. P. and Meyer, H.-D. 2013. "Reconciling Efficiency with Excellence and Fairness: Proposals for Policy and Practice." In Fairness in Access to Higher Education in a Global Perspective: Reconciling Excellence, Efficiency, and Justice. Edited by Hanz-Deiter Meyer, Edward P. St. Jon, Maia Chankseliani and Lina Uribe, 289-307. Rotterdam: Sense. 
Susanti, D. 2011. "Privatisation and Marketisation of Higher Education in Indonesia: the challenge for equal access and academic values." Higher Education 61 (2), 209-218.

Susanto, S., and Nizam, M. 2009. "Gadjah Mada University, Indonesia." In Higher education reforms: Institutional restructuring in Asia. Edited by N Vargehese, 53-80. Paris: UNESCO IIEP.

Tilak, J. B. G. (2010) "Higher Education, Poverty and Development." Higher Education Review 42 (2) 23-45.

Torres, C., and D. Schugurensky. 2002. "The Political Economy of Higher Education in the Era of Neoliberal Globalization: Latin America in Comparative Perspective." Higher Education 43: 429-455.

UN (September 2015) Sustainable Development Goals.

http://www.un.org/sustainabledevelopment/sustainable-development-goals/

Unterhalter, E., and Carpentier, V. 2010. Global inequalities and higher education: Whose interests are we serving? London: Palgrave Macmillan.

Uribe, L. 2013. “Access Policy and Social Justice in Higher Education.” In Fairness in Access to Higher Education in a Global Perspective: Reconciling Excellence, Efficiency, and Justice. Edited by Hanz-Deiter Meyer, Edward P. St. Jon, Maia Chankseliani and Lina Uribe, 111-127. Rotterdam: Sense.

von Luebke, C. 2011. Democracy in progress - or oligarchy in disguise? The politics of decentralized governance in Post-Suharto Indonesia, Discussion Paper Series, University of Freiburg, Department of International Economic Policy, No. 15. http://www.vwl.unifreiburg.de/iwipol/discussion_papers/DP15_luebke_democracy_in_progress.pdf

Welch, A. R. 2007. "Blurred vision?: Public and private higher education in Indonesia." Higher Education 54 (5) 665-687.

Widoyoko, J. D. 2010. "The education sector: the fragmentation and adaptability of corruption." In The state and illegality in Indonesia. Edited by Edward Aspinall and Gerry van Klinken, 165-188. Leiden: KITLV Press

World Bank. 2002. Constructing Knowledge Societies: New Challenges for Tertiary Education. Washington, D.C: World Bank. 